\title{
Correlation, regression estimates and heterosis of Archachatina marginata snails in
} Calabar, Nigeria

${ }^{*}$ Ibom, L. A., ${ }^{\text {OOkon, B. and }}{ }^{2}$ Okon, F. I.

${ }^{\prime}$ Department of Animal Science, University of Calabar, Calabar, Nigeria.

${ }^{2}$ Department of Environmental Health, College of Health Technology, Calabar, Nigeria.

Abstract "Corresponding author: ibomlawrence@gmail.com; +2348033508663

Eighty sexually mature Archachatina marginata snails, forty each of the black skinned and white skinned ectotypes were used in a study to estimate heterosis, correlation and regression. Data collected on the snails and their eggs included body weight (BWT), shell length (SLH), shell width (SWH), "mouth" length (MLH) and "mouth" width (MWH); and egg weight (EWT), egg length (ELH) and egg width (EWH), respectively. These data were used to estimate correlations between pairs of traits, heterosis and to predict weight from other morphometric traits among three mating groups [black skinned $x$ black skinned (BAM $X$ BAM), white skinned $x$ white skinned (WAM $X$ WAM) and their cross BAM XWAM)]. Results obtained from the study showed that evaluated traits expressed strong, positive and highly significant $(P<0.01)$ correlation values that ranged from $r_{p}=0.86$ to $r_{p}=0.99$ among the snails mating groups. The correlation values of traits evaluated on eggs laid by these snails ranged from mild $\left(r_{p}=0.49\right)$ through moderate $\left(r_{p}=0.59, r_{p}=0.70\right)$ to strong/close $\left(r_{p}\right.$ $=0.89)$. Regression estimates values obtained ranged from mild (1.30) to high (6.25), and shell width best predicted hatchlings body weight in the black skinned $x$ black skinned (BAM $X$ BAM) mating group, while "mouth" length best predicted hatchlings body weight in the white skinned $x$ white skinned (WAM X WAM) mating group. Traits evaluated for percent heterosis expressed positive and significant $(P<0.05)$ values between the mating groups, with the crossbred (BAMXWAM) mating group having advantage over the purebred (BAMX $B A M$ and WAM XWAM) mating groups. It could therefore be concluded that in the face of appropriate selection programme, heterosis can be exploited to improve snails reproductive and growth traits. It can thus be recommended that having information regarding the association of weight with other contributing traits/parameters is crucial before starting any breeding programme.

Keywords: Correlation, Estimates, Heterosis, Regression, Snails

\section{Introduction}

Land snails are among the most important primary consumers in the terrestrial ecosystem. The need to establish means of improved land snails production and productivity has taken new urgency as the species face increased threat of extinction as a result of human activities in an attempt to boost the animal protein supply of Nigerians. The Achatinidae gastropod family is one of the land snails of economic importance. Raut and Barker (2002) reported that the family is native to Africa and is represented by about 200 species and 13 genera. The giant African land snail (GALS) is a reservoir of some valuable traits, like other livestock of African origin (Ibom, 2009 and Ibom et al. 2012a; 2012b). They are also a vital conduit for energy flow to upper trophic levels in the ecosystem by serving as prey to numerous invertebrate and vertebrate predators (Dillon, 2000). The precious genetic resource of snails as a species has not been realized and so is yet to find a place in the Nigeria livestock census chart (Ibom et al., 2014). Snails are among 


\section{Correlation, regression estimates and heterosis of Archachatina marginata snails}

the few animals that provide a direct measurable connection to their individual lives, even after death, through their shell studies on morphology (i.e. size and shape) and has constituted an important aspect in many biological fields - paleontology, anatomy, ecology, systemic and to study phylogeny tree (Madan et al., 2015). Measurements of body weight and shell parameters provide a faster and easier means of determining the percentage growth rate of measurable traits in animals, including snails (Ganiyu et al., 2016). Genetic progress for body weight has been accomplished by continuous selection especially as it tends to bring about change in the genetic correlations among traits. Genetic improvement of any snail breed in order to increase its contribution to the much needed animal protein in Nigeria is inevitable and could be achieved by estimates of genetic correlations among performance traits in the breeding objective and development of selection programme for effective planning.

Obtaining biomass data from preserved specimens is facilitated by regressions because length is a relatively stable measure compared to mass (Wetzel et al., 2005). Regressions provide mass estimates without sacrificing animals, which may not be feasible for desirable or protected taxa, because repeatedly sampling the same population can cause bias (Cahill et al., 2001). Obaza and Ruehl (2013) stated that length-mass regressions enable quick estimation of individual biomass to assist estimating standing stock and production. Olawoyin and Ogogo (2006) reported one trait (shell length) as a better predictor of body weight for growing snails, while Okon and Ibom (2011) reported two morphometric traits (shell length and shell width) as better predictors of body weight in juvenile $A$. marginata snails. Combining multiple length measures should improve predictive power and provide more accurate biomass estimates for snails because they exhibit a diversity of shapes (Obaza and Ruehl, 2013). This corroborates the position of Groesbeck (2003) and Ibom et al. (2017) that the use of several parameters/traits as independent variables in multiple regression equations is likely to give more accurate and reliable results than the use of a single trait. The experimental estimation of heterosis (the mean performance of hybrid progeny relative to the mid-parent value) provides relevant information on its trends for the traits being considered. However, Clift (2010) reported that heterosis is expected to be mainly contributed by mildly deleterious alleles, and maximized for moderate to intermediate selection coefficients (Crow, 2008). Crow (2008) further reported that heterosis is predicted to be high in small populations with gene flow and to increase with population structure, whereas it is reduced by inbreeding. Farmers had used hybrid vigour or positive heterosis to enhance growth and reproductive performance of farm animals (e.g., cattle, sheep, pigs and poultry), but this is rarely applied to snails.

This study was therefore undertaken to obtain heterosis, correlation coefficients and regression estimates of morphometric traits and predicting body weight from associated morphometric traits of $A$. marginata snails. The results will add to the scanty information in literature.

\section{Materials and methods Studylocation}

The research was carried out at the Department of Animal Science Snail Sanctuary, University of Calabar, Calabar, Nigeria. Calabar is situated within the geographical area between latitude $4^{0} 58^{\prime}$ and $15^{\circ} 39^{\prime} \mathrm{N}$ and longitude $8^{\circ} 17^{\prime}$ and $10^{\circ} 43^{\prime} \mathrm{E}$ of the equator, with annual 


\section{Ibom, Okon and Okon}

temperature and rainfall ranges of $25^{\circ} \mathrm{C}$ to $28^{\circ} \mathrm{C}$ and $1260 \mathrm{~mm}$ to $1280 \mathrm{~mm}$, respectively. The relative humidity rarely drops below $60 \%$ and fluctuates between $90 \%$ and $100 \%$ most months of the year (NIMET, 2018).

\section{Experimental animal and management}

Eighty (80) sexually mature Archachatina marginata snails, forty (40) each of the black skinned and white skinned ectotypes sorted out of an earlier study were used for this study. The snails were grouped into three treatments (mating groups) on the basis of skin (foot) colour, namely; black skinned x black skinned (BAM X BAM), white skinned $\mathrm{x}$ white skinned (WAM X WAM) and their cross (BAM X WAM). This was done to ascertain that eggs and hence baby snails (snailets or hatchlings) resulting from the mating are genetically purified. The black skinned and white skinned (albino) snails had weight ranges of 56.22 - $67.38 \mathrm{~g}$ and 55.54 - $66.52 \mathrm{~g}$, respectively. Natural mating technique was used in the mating, with ratio of $1: 1$ (two snails per cell/cage). Egg clutches laid were collected manually and incubated in an improvised incubator (plastic containers filled with sterilized loamy soil). This was done to avoid the eggs being preyed upon by the mother snails. Data collected on the snails [body weight (BWT), shell length (SLH), shell width (SWH), "mouth" length (MLH) and "mouth" width (MWH)] and eggs [egg weight (EWT), egg length (ELH) and egg width $(\mathrm{EWH})$ ] were analyzed to estimate correlations between pairs of traits using Pearson's correlation test of SPSS (2014) statistical programme. The data were also used to estimate heterosis and to predict body weight from other morphometric traits.

The model used for this study was:

$\mathrm{Y}_{\mathrm{ij}}=\mu+\mathrm{G}_{\mathrm{i}}+\mathrm{e}_{\mathrm{ij}}$
Where:

$\mathrm{Y}_{\mathrm{ij}}=$ Single observation

$\mu=$ Common mean

$\mathrm{G}_{\mathrm{i}}=$ Effect of ectotype (genotype) on

reproduction

$\mathrm{e}_{\mathrm{ij}}=$ Random error [identically, independently and normally distributed with zero mean and constant variance (iind $\left.\left.\sim 0, \delta^{2}\right)\right]$

The general prediction model used was:

$$
\mathrm{Y}_{\mathrm{i}}=\mathrm{a}+\underset{\mathrm{i}=\mathrm{k}}{\mathrm{k} \mathrm{b}_{\mathrm{i}} \mathrm{X}_{\mathrm{i}}}+\mathrm{e}_{\mathrm{i}}
$$

Where:

$\mathrm{Y}_{\mathrm{i}}=$ Dependent variable (body weight)

$\mathrm{a}=$ Intercept on the $\mathrm{Y}$-axis

$b_{i}=$ Partial regression coefficients

$\mathrm{X}_{\mathrm{i}}=$ Independent variables (i.e. the dimensional shell measurements)

$\mathrm{e}_{\mathrm{i}}=$ Random error.

Percent Heterosis was estimated according to the formula by Ibe (1998).

$\%$ Heterosis $=\frac{\mathrm{H}_{1}-\overline{\mathrm{P}}}{\overline{\mathrm{P}}} \times \frac{100}{1}$

Where:

$\mathrm{H}_{1}=$ Average performance of offspring

$\overline{\mathrm{P}}=$ Average performance of parents

\section{Results and discussion}

The phenotypic correlation estimates of traits evaluated on the mating groups (blackskinned X blackskinned, BAM X BAM) and (whiteskinned $\mathrm{x}$ whiteskinned, WAM X WAM) are presented in Table 1. The results showed that the pairs of traits evaluated on the mating groups expressed strong, positive and highly significant $(\mathrm{P}<0.01)$ correlation values. Body weight (BWT) and "mouth" length (MLH) had positive relationship of $r_{p}=0.86$ for BAM X BAM mating group and $r_{p}=0.96$ for WAM $\mathrm{X}$ WAM mating group. 
Correlation, regression estimates and heterosis of Archachatina marginata snails

Table 1: Correlation ( $\mathrm{r}_{\mathrm{p}}$ ) estimates of traits evaluated on $\boldsymbol{A}$. marginata snails mating groups (BAM X BAM and WAM X WAM)

\begin{tabular}{lccccc}
\hline \multicolumn{5}{c}{ BAM X BAM } \\
\hline BWT & BWT & SLH & SWH & MLH & MWH \\
SLH & 1.00 & $0.97^{* *}$ & $0.99^{* *}$ & $0.86^{* *}$ & $0.98^{* *}$ \\
SWH & $0.98^{* *}$ & 1.00 & $0.96^{* *}$ & $0.89^{* *}$ & $0.89^{* *}$ \\
MLH & $0.98^{* *}$ & $0.99^{* *}$ & 1.00 & $0.98^{* *}$ & $0.99^{* *}$ \\
MWH & $0.96^{* *}$ & $0,97^{* *}$ & $0.99^{* *}$ & 1.00 & $0.98^{* *}$ \\
& $0.99^{* *}$ & $0.98^{* *}$ & $0.98^{* *}$ & $0.99^{* *}$ & 1.00 \\
& BWT & SLH & SWH & MLH & MWH \\
\hline
\end{tabular}

WAM X WAM

$\overline{\mathrm{BAM}}=$ Blackskinned $A$. marginata snail ectotype, WAM $=$ White skinned $A$. marginata snail ectotype, BWT = Body Weight, SLH = Shell Length, SWH = Shell Width, MLH = "Mouth" Length, MWH = "Mouth" Width. ${ }^{* *}=$ Significant $(\mathrm{P}<0.01)$.

The pair of shell length (SLH) and shell width (MWH) also expressed a correlation value of $r_{p}=0.96$ in the BAM X BAM mating group. Besides, the pairs of body weight (BWT) and shell width (SWH) and, shell width (SWH) and "mouth" width $(\mathrm{MWH})$ were most strongly correlated $\left(\mathrm{r}_{\mathrm{p}}=\right.$ 0.99 ) in the BAM X BAM mating group, while the most strongly correlated $\left(r_{p}=\right.$ 0.99) pairs of traits in the WAM X WAM mating group were body weight (BWT) and "mouth" width (MWH); shell length (SLH) and shell width (SWH); shell width (SLH) and "mouth" length (MLH); and "mouth" length (MLH) and "mouth" width (MWH) (Table 1). These were followed by the pairs of body weight (BWT) and "mouth" width (SWH), shell width (SWH) and "mouth" length (MLH) and, "'mouth length (MLH) and "mouth" width (MWH) in the BAM X BAM mating group, body weight (BWT) and shell length (SLH), body weight
(BWT) and shell width (SWH), shell length (SLH) and "mouth" width (MWH) and, shell width (SWH) and "mouth" width $(\mathrm{MWH})$ in the WAM X WAM mating group which expressed correlation value of $r_{p}=$ 0.98 and were therefore closely correlated. The pairs of body weight (BWT) and shell length (SLH), and shell length (SLH) and "mouth" length (MLH) in the BAM X BAM and the WAM $X$ WAM mating groups, respectively were also closely correlated with correlation value of $r_{p}=0.97$ (Table 1). The pairs of shell length (SLH) and "mouth width (MWH); and shell length (SLH) and "mouth" length (MLH) were also closely correlated with a correlation value of $r_{p}=0.89$ in the BAM X BAM mating group.

The phenotypic correlation estimates of traits evaluated on eggs laid by the $A$. marginata snails mating groups (BAM X BAM and WAM X WAM) are presented in Table 2.

Table 2: Correlation ( $\left.\mathrm{r}_{\mathrm{p}}\right)$ estimates of traits evaluated on eggs of $\boldsymbol{A}$. marginata snails mating groups (BAM X BAM and WAM X WAM)

\begin{tabular}{lccc}
\hline \multicolumn{3}{c}{ BAM X BAM } & \\
\hline & EWT & ELH & EWH \\
EWT & 1.00 & $0.48^{*}$ & $0.49^{*}$ \\
ELH & $0.59^{*}$ & 1.00 & $1.00^{* *}$ \\
EWH & $0.70^{* *}$ & $0.89^{* *}$ & 1.00 \\
& EWT & ELH & EWH \\
\hline
\end{tabular}

WAM X WAM

$\overline{\text { BAM }}=$ Blackskinned $A$. marginata snail ectotype, WAM $=$ White skinned A. marginata snail ectotype, EWT $=$ Egg Weight, ELH $=$ Egg Length, EWH = Egg Width. ${ }^{*}=$ Significant $(\mathrm{P}<0.05),{ }^{* *}=$ Significant $(\mathrm{P}<0.01)$ 


\section{Ibom, Okon and Okon}

The results showed that all the pairs of traits evaluated on the eggs of these mating groups had positive correlations. The correlation estimates between these traits ranged from $r_{p}=0.48$ to $r_{p}=1.00$ and were significant $(\mathrm{P}<0.01)$. The pairs of egg weight (EWT) and egg length (ELH), and egg weight (EWT) and egg width (EWH) expressed low correlation values $\left(r_{p}=0.48\right.$ and $r_{p}=0.49$, respectively) in the BAM X BAM mating group (Table 2). Egg width (EWH) and egg length (ELH) expressed high or close correlation value $\left(r_{p}=0.89\right)$ in the WAM X WAM mating group, while egg weight (EWT) and egg length (ELH), and egg weight (EWT) and egg width (EWH) expressed moderate to high correlation values $\left(r_{p}=0.59\right.$ and $\left.r_{p}=0.70\right)$, respectively in the same mating group (Table 2).

The positive correlation values expressed by the pairs of traits evaluated on the mature snails and their eggs could mean that the traits are influenced by the same genes in the same direction. The positive correlation could also suggest that there are direct relationships between the pairs of traits, and that weight increment in snails is as a result of increase in the size of corresponding traits (Ibom et al., 2017). The high degree of correlation among traits indicated that selection for one trait will lead to improvement in the other trait. Variations in phenotypic correlation among measured traits revealed that the influence of genes on these different traits differ from one to another. The results of phenotypic correlations obtained in this study agreed with the positions of Falconer (1989) and Ehiobu and Kyado (2000) that correlation could be high or low and/or positive or negative between traits. The significant positive correlation values recorded by some pairs of egg traits in this study compared favourably with earlier reports of Ibom (2009) and Ibom et al. (2012) who reported $r_{p}=0.49$ to $r_{p}=1.00$ as the range of phenotypic correlation values for eggs of adult $A$. marginata var. saturalis. Okon and Ibom (2011) reported range values of $r_{p}=$ 0.71 to $\mathrm{r}_{\mathrm{p}}=0.82$ for $A$. marginata snails. The results of mature snails also compared favourably with the findings of Etta et al. (2015) as correlation range values for the pairs of traits evaluated in A. marginata snail breed. Besides, the correlation results of traits evaluated on mature snails compared favourably with the correlation range values $\left(r_{p}=0.51\right.$ to $\left.r_{p}=0.94\right)$ reported by Ibom et al. (2017) for mature snails of the same breed. The disparity between correlation values obtained in this study and those in available literature could be attributed to differences in ages of snails used, management technique adopted, number of eggs used and the statistical methods of analyses.

Table 3 shows the heterotic values of reproductive traits estimated on BAM X BAM, WAM X WAM and BAM X WAM mating groups of $A$. marginata snails.

Table 3: Heterosis (\%) values of reproductive traits estimated on mating groups (BAM X BAM, WAM X WAM and BAM X WAM) of A. marginata snails

\begin{tabular}{llcccc}
\hline Trait & Age & BAM X BAM & WAM X WAM & BAM X WAM & SE \\
\hline Egg weight $(\mathrm{g})$ & At lay & $6.78^{\mathrm{b}}$ & $1.26^{\mathrm{c}}$ & $11.17^{\mathrm{a}}$ & 0.036 \\
Egg length $(\mathrm{mm})$ & At lay & $10.76^{\mathrm{b}}$ & $4.40^{\mathrm{c}}$ & $12.57^{\mathrm{a}}$ & 0.040 \\
Egg width $(\mathrm{mm})$ & At lay & $6.35^{\mathrm{b}}$ & $5.60^{\mathrm{b}}$ & $7.69^{\mathrm{a}}$ & 0.023 \\
Snailet weight $(\mathrm{g})$ & At hatch & $3.45^{\mathrm{b}}$ & $2.55^{\mathrm{c}}$ & $4.52^{\mathrm{a}}$ & 0.036 \\
Snailet shell length $(\mathrm{mm})$ & At hatch & $6.91^{\mathrm{c}}$ & $7.46^{\mathrm{b}}$ & $8.22^{\mathrm{a}}$ & 0.023 \\
Snailet shell width $(\mathrm{mm})$ & At hatch & $6.54^{\mathrm{b}}$ & $6.45^{\mathrm{b}}$ & $11.83^{\mathrm{a}}$ & 0.023 \\
\hline
\end{tabular}

BAM = Black-skinned Archachatina marginata

WAM = White-skinned Archachatina marginata

${ }^{\mathrm{abc}}$ Means with different superscript along the same row are significantly different $(\mathrm{P}<0.05)$ 


\section{Correlation, regression estimates and heterosis of Archachatina marginata snails}

The estimates showed that all traits expressed positive and significant $(\mathrm{P}<0.05)$ heterosis between the mating groups. The BAM X WAM mating group had advantage over the other two mating groups (BAM X BAM and WAM X WAM) and corroborated the positions of Ibom et al. (2014) and Okon et al. (2017). This could suggest that the parent snails had good combining ability and appreciable mating is possible between the black skinned (BAM) and the white skinned (WAM) snails. Besides, it could be that the considered traits are heritable, hence Ibom et al. (2014) noted that heterosis/hybrid vigour can be exploited to improve snails reproductive and growth traits if appropriate selection programme is applied. Clift (2010) reported that heterosis tends to be greater for traits that have low heritability (i.e. reproductive traits) as shown in the results of this study (Table 3 ), and smaller for traits that are highly heritable (i.e. growth rate). Nwakpu and Omeje (2005) also reported that the effects of heterosis are most often but not always positive, and depends mainly on choice of parents and selection pressure applied in parental lines (breeds). The heterotic values of egg weight, egg length and egg width at lay were $6.78 \%, 1.26 \%$ and $11.17 \% ; 10.76 \%, 4.40 \%$ and $12.57 \%$; and $6.35 \%, 5.60 \%$ and $7.69 \%$, respectively for BAM X BAM, WAM X WAM and BAM X WAM mating groups (Table 3 ). The positive nature of these values were similar to the values reported by Ibom (2009) and Ibom et al. (2014) for egg traits at lay of the same snail breed. However, the results of this study were lower than the values reported by these authors, and this could be as a result of the differences in ages and sizes of parent snails used, the number of eggs considered and the volume of data analyzed. The heterotic values of hatchlings weight, hatchlings shell length and hatchlings shell width at hatch were $3.45 \%, 2.55 \%$ and $4.52 \%$; $6.91 \%, 7.46 \%$ and $8.22 \%$; and $6.54 \%$, $6.45 \%$ and $11.83 \%$, respectively for BAM X BAM, WAM X WAM and BAM X WAM mating groups. The magnitude of heterotic effects obtained for hatchling traits in this study were also lower than the values reported by Ibom (2009) and Ibom et al. (2014) for hatchlings of the same snail breed at hatch. Besides, the heterotic values obtained for shell traits in this study were lower than the values reported by Okon et al. (2017) for juvenile A. marginata snails, and this confirmed that reproductive traits have low heritability while growth traits have high heritability. The trend of heterosis results could be attributed to the differences in the ages and sizes of parent snails and hatchlings considered and the volume of data used. The heterosis results of this study could suggest that the genes responsible for the expression of these traits are favourable to reproduction. The differences between the results of this study and that in available literature could be attributed to the sizes of parent snails used, the number of eggs and hatchlings used, and the technique adopted in the estimation. The regression estimates obtained for BAM X BAM mating group hatchlings are presented in Table 4a. The estimates showed that the association (b) between body weight and other phenotypic traits was positive, low $(\mathrm{P}<0.05)$ and ranged from mild (1.30) to high (6.25). The estimates revealed that shell width best predicted the hatchlings body weight.

Table 4a: Regression equation of traits estimated on BAM X BAMnating group of A. marginata snails

\begin{tabular}{lcccc}
\hline Trait & Equation & $\mathbf{B}$ & $\mathbf{r}^{2}$ & $\mathbf{p}$-value \\
\hline BWT/SLH & $\mathrm{Y}=-0.73+1.30 \mathrm{X}$ & $0.98^{*}$ & 0.96 & $\mathrm{p}<0.05$ \\
BWT/SWH & $\mathrm{Y}=-5.50+6.25 \mathrm{X}$ & $0.99^{*}$ & 0.97 & $\mathrm{p}<0.05$ \\
BWT/MLH & $\mathrm{Y}=-1.30+2.40 \mathrm{X}$ & $0.66^{*}$ & 0.44 & $\mathrm{p}<0.05$ \\
BWT/MWH & $\mathrm{Y}=-1.29+4.15 \mathrm{X}$ & $0.99^{*}$ & 0.98 & $\mathrm{p}<0.05$ \\
\hline
\end{tabular}

BWT = Body Weight, SLH = Shell Length, SWH = Shell Width, MLH = "Mouth" Length,

MWH = "Mouth" Width, * = Correlation is significant $(p<0.05)$. 


\section{Ibom, Okon and Okon}

The coefficient of determination $\left(\mathrm{r}^{2}\right)$ varied from 0.44 to 0.98 , indicating that the variability in body weight of hatchlings can be explained by $44 \%$ to $98 \%$ of changes in other phenotypic traits evaluated.

The regression estimates obtained for WAM $\mathrm{X}$ WAM mating group hatchlings are presented in Table $4 \mathrm{~b}$. The results followed a similar trend like that of the BAM X BAM mating group, with positive and low
$(\mathrm{P}<0.05)$ association (b) between body weight and other phenotypic traits that ranged from mild (1.40) to medium (4.51). The body weight of hatchlings of this mating group was best predicted by "mouth" length. The coefficient of determination $\left(\mathrm{r}^{2}\right)$ varied from 0.37 to 0.96 , indicating that the variability in body weight of hatchlings of this mating group can be explained by $37 \%$ to $96 \%$ of changes in other phenotypic traits.

Table 4b: Regression equation of traits estimated on WAM X WAM mating group of . marginata snails

\begin{tabular}{lcccc}
\hline Trait & Equation & B & $\mathbf{r}^{2}$ & p-value \\
\hline BWH/SLH & $\mathrm{Y}=-1.04+1.40 \mathrm{X}$ & $0.63^{*}$ & 0.40 & $\mathrm{p}<0.05$ \\
BWH/SWH & $\mathrm{Y}=-3.23+4.30 \mathrm{X}$ & $0.62^{*}$ & 0.38 & $\mathrm{p}<0.05$ \\
BWH/MLH & $\mathrm{Y}=-3.21+4.51 \mathrm{X}$ & $0.98^{*}$ & 0.96 & $\mathrm{p}<0.05$ \\
BWH/MWH & $\mathrm{Y}=-0.88+3.88 \mathrm{X}$ & $0.61^{*}$ & 0.37 & $\mathrm{p}<0.05$ \\
\hline
\end{tabular}

BWT = Body Weight, SLH = Shell Length, SWH = Shell Width, MLH = "Mouth" Length,

MWH $=$ "Mouth" Width, * = Correlation is significant $(\mathbf{p}<0.05)$.

The regression (b) estimates of this study agreed with earlier reports by Okon et al. (2010a and 2010b) that using any one of morphometric traits in a simple regression was a better predicator of hatchlings/juveniles body weight of $A$. marginata and A. achatina. Similarly, Olawoyin and Ogogo (2006) had earlier reported only one trait (shell length) as a better predictor of body weight for growing snails. The regression results of this study corroborated the reports of these authors, that shell parameters/traits are better predictors of body weight in snails.

\section{Conclusion}

This study revealed that all the pairs of phenotypic traits evaluated on the mother snails and their eggs expressed positive and significant correlations. Besides, any one of these phenotypic traits (shell width and/or "mouth" length) can serve as a better predicator of A. marginata hatchlings body weight when used in a simple regression, and that $37 \%$ to $98 \%$ variability in the body weight of A. marginata hatchlings can be explained by changes in other phenotypic traits. All the traits expressed positive and significant $(\mathrm{P}<0.05)$ heterosis between the mating groups, hence in the face of appropriate selection programme, heterosis can be exploited to improve snails reproductive and growth traits.

It could be recommended that having information regarding the association of body weight with other contributing traits/parameters is crucial before starting any breeding program and selection can therefore be based on production and functional traits.

\section{References}

Cahill, J. F., Castelli, J. P. and Casper, B. B. 2001. The herbivore uncertainty principle: visiting plants can alter herbivory. Ecology, 82:1401 1409.

Clift, L. 2010. Hybrid vigour or heterosis in farm animals, experiences with dairy cattle crossbreeding in New 
Correlation, regression estimates and heterosis of Archachatina marginata snails

Zealand. Proceedings of the $53^{\text {rd }}$ Annual Meeting of the European Association for Animal Production, (AMEAAP'10), Winnipeg, MB., Canada, Pp. $1-4$.

Crow, J. F. 2008. Mid-century controversies in population genetics. Annual Revolutionary Genetics. 42:1-16.

Dillon, R. T. 2000. The ecology of fresh water mollusc. Cambridge University Press. Cambridge, UK. Pp. 524.

Ehiobu, N. G. and Kyado, J. A. 2000. Heritability, Repeatability and Genetic correlation of Swine. Proceedings of the $25^{\text {th }}$ Annual Conference of Nigerian Society for Animal Production (NSAP). March 19 - 22, 2000. Umudike, Nigeria. Pp. 260-261.

Etta, H. E., Okon, E. A. and Ekpe, P. A. 2015. Comparative phenotypic Assessment of two snail Breeds Archachatina marginata (S) and Achatina fulica (L) in Calabar, Cross River State. Proceedings of the $4^{\text {th }}$ International Conference/Workshop on Giant African Land Snails. $1^{\text {st }}-4^{\text {th }}$ June, 2015. Awka, Nigeria. Pp. 44-45.

Falconer, D. S. 1989. Introduction to Quantitative Genetics. ${ }^{\text {rd }}$ ed. Burat Mill, England. Longman Group Limited. Pp. $162-169$.

Ganiyu, S. O., Olowofeso, O., Adeyemi, Y. V. and Sanda, A. J. 2016. Strength and Nature of Relationship between Body weight and Linear Body Measurements in Anak White Broiler Chickens in Abeokuta, Nigeria. Proceedings, $41^{\text {st }}$ Annual Conference of Nigerian Society for Animal Production (NSAP), 20 24 March, 2016. Federal University of Agriculture, Abeokuta, Nigeria.
Pp. 23-26.

Groesbeck, C. N. 2003. Use of heart girth to estimate the weight of finishing pigs. Kansas State University Cooperative Extension Service Swine Update Newsletter-Spring.

Ibe, S. N. 1998. An Introduction to Genetics and Animal Breeding. Longman Nigeria Plc, Ikeja, Nigeria. Pp. 150.

Ibom, L. A. 2009. Variations in reproductive and growth performance traits of Whiteskinned x Black-skinned African giant snail hatchlings [Archachatina marginata (Swainson)] in Obubra, Nigeria. Ph. D. Thesis, Department of Animal Science, University of Calabar, Calabar, Nigeria. Pp. 166.

Ibom, L. A., Okon, B. and Bassey, B. E. E. 2012a. Egg traits, hatchability and snailet survivability of blackskinned, white-skinned and crossbred Archachatina marginata snails. International Journal of Agriculture, Science, Bioresource and Engineering Research 1(1):10 -18 .

Ibom, L. A., Okon, B., Adinya, I. B. and Okon, F. I. 2012b. Reproductive Performance and Correlations Among Egg Traits of Two Ectotypes of Adult Snail (Archachatina marginata Var. Saturalis) in the Humid Tropics. World Journal of Zoology. $7(2): 113-117$.

Ibom, L. A., Okon, B. and Asuquo, L. E. 2014. Heterosis of Body Weights and Egg Weights of $\mathrm{F}_{1}$ Snails (Archachatina marginata var. saturalis) in Obubra, Nigeria. Journal of Biology, Agriculture and Healthcare. 4(17):120-123.

Ibom, L. A., Okon, B. and Emah, B. B. 


\section{Ibom, Okon andOkon}

2017. Association Between Body Weight and Dimensional Shell Traits of Snails (Archachatina marginata and Achatina achatina). Nigerian Journal of Animal Science. 19(1):50-61.

Madan, S., Singh, S. and Jauhari, R. K. 2015. Morphometric Analysis of Freshwater Snails Along with associated Planktonic Community at Dudhlee in Doon Valley (Uttarakland). Journal of Global Biosciences, 6(4):2604-2610.

NIMET 2018. Nigeria Metrological Agency, Margaret Ekpo International Airport, Calabar, Nigeria.

Nwakpu, P. E. and Omeje, S. I. 2005. Influence of genotype and weight of gilts on the litter size and litter growth of inbred Native by Largewhite pig crosses. Tropical Journal of Animal Science, 8:1 -4.

Obaza, A. and Ruehl, C. B. 2013. Regressions for Estimating Gastropod Biomass with Multiple Shell Metrics. Malacologia, 56(1 2):343-349.

Okon, B., Ibom, L. A., Williams, M. E. and Etukudo, O. M. 2010a. Effects of Parity on Breeding and Morphometric Traits of Eggs and Hatchlings of $F_{1}$ Crossbred of Snails (Archachatina marginata var. saturalis). Journal of Agriculture, Biotechnology and Ecology. 3(1):36-43.

Okon, B., Ibom, L. A., Williams, M. E. and Akwa, N. T. 2010b. Parity Effects on Breeding and Morphometric Traits of Eggs and Hatchlings of Purebred Albino Snails [Archachatina marginata (Swainson)]. Journal of Agriculture, Biotechnology and Ecology.3(1):44-54.
Okon, B. and Ibom, L. A. 2011. Phenotypic correlation and body weight prediction using morphometric traits of snails in Calabar, Nigeria. Ethiopian Journal of Environmental Studies and Management, 4 (3):7-11.

Okon, B., Ibom, L. A., Sam, I. M. and Ibiang, N. O. 2017. Comparison of growth and heterosis of body parameters of two varieties of snail [Archachatina marginata (Swainson, 1821)] and their crosses reared under tropical conditions. Journal of Animal Science and Veterinary Medicine. 2:1-7.

Olawoyin, O. O. and Ogogo, A. U. 2006. Prediction of optimum stocking density in growing African Giant land snails. Tropical Journal of Animal Science, 9(2):75-84.

Raut, S. K. and Barker, G. M. 2002. Achatina fulica Bowdich and other Achatinidae as pests in tropical agriculture. In: Barker, G. M. ed. Molluscs as crop pests. Wallingford, CABI Publishing.

SPSS 2014. Scientific Package for Social Sciences.

Wetzel, M. A., Leuchs, H. and Koop, J. H. E. 2005. Preservation effects on wet weight, dry weight and ashfree weight biomass estimates of four common estuarine macroinvertebrates: no difference between ethanol and formalin. Helgoland Research, 59:206 213.

Received: $12^{\text {th }}$ April, 2019

Accepted: $15^{\text {th }}$ August, 2019 